Mindaugas Butkus,

$P h D$, Associate Professor of the Department of Economics Engineering, Vilnius Gediminas Technical University (Vilnius, Lithuania);

Alma Maciulyte-Sniukiene,

PhD, Lecturer of the Department of Business Technologies and Entrepreneurship, Vilnius Gediminas Technical University (Vilnius, Lithuania);

Kristina Matuzeviciute,

$P h D$, Associate Professor of the Department of Economics Engineering, Vilnius Gediminas Technical University (Vilnius, Lithuania)

Vida Davidaviciene,

PhD, Professor of the Department of Business Technologies and Entrepreneurship, Vilnius Gediminas Technical University (Vilnius, Lithuania)

\title{
SOCIETY'S ATTITUDES TOWARDS IMPACT OF IMMIGRATION: CASE OF EU COUNTRIES
}

One of the most pressing problems nowadays attracting attention of EU citizens is the integration of immigrants. During the recent period immigration flows to the EU, especially external, were growing considerably - the number of international immigrants in the EU has increased by 57.5 percent over $2000-2015$. One of the factors leading to successful integration of immigrants is attitudes towards them regarding their impact on countries' socio-economic, cultural or other transformation. Empirical studies show that immigration can lead to both positive and negative effects on countries' demography, economy, culture and criminogenic situation depending on the immigrants' education, age, gender and other characteristics. Nevertheless, even if immigration leads to a positive transformation of the country, society's attitude towards immigration can be negative and this can complicate the process of integration. For this reason, it is important to investigate not only the effects of immigration on countries' demography, economy, culture and other areas, but also to investigate society's attitudes towards benefits and losses of immigration. We employed binary logistic regression to analyse the EU society's attitudes towards consequences of immigration. The results show that public attitudes toward consequences of immigration are largely negative, especially towards impact on criminogenic situation and this does not match actual impact empirically researched by other authors and presented in the literature review.

Keywords: attitudes toward immigrants, immigration consequences, threat-benefit model, immigration benefits, immigration costs.

DOI: 10.21272/mmi.2018.1-26

Introduction. Recently one of the most pressing problems in the European Union is the integration of immigrants. The flow of immigrants to the EU has increased considerably over the last ten-years and especially the flow of external immigration. According to United Nations (2015), during the period of 2000-2015, the number of international migrants in the EU has increased by 57.5 percent (from 34.3 to 54.1 million). In 2015, the highest international migrants to population ratio was in Luxemburg (44\%), Austria, Cyprus, Sweden (17\%), Ireland (16\%) and Germany, Estonia (15\%). This ratio over the same period increased mostly in Luxembourg (by 12\% points), Cyprus, Spain (by $9 \%$ points), Ireland (by $7 \%$ points), Sweden, Italy (by 6\% points) and United Kingdom (by 5\% points).

One of the determinants of successful integration of the immigrants is society's attitudes towards them regarding their impact on countries' socio-economic, cultural, security and other transformations. Previous studies (Smith and Edmondson [1]; Auerbach and Oreopoulos [2]; Lee and Miller [3]; Mayr [4]; Jiroudkova et al. [5]; Simionescu et. al. [6]; Kerr and Kerr [7]; Hinojosa-Ojeda [8]; Berzinskiene et. al. [9]; Docquier et. al. [10]; Strielkowski et al. [11]; Metelski and Mihi-Ramirez [12]; Tubadji and Nijkamp [13]; Byrne and Dixon [14]; Strielkowski et al. [15]; Butkus et. al. [16; 17]; Kushnirovich [18]; Sanchez-Pages 
and Garcia [19]; Bove and Elia [20]; Lincényi, [21]; Kordík and Kurilovská, [22]; Beinoravičius and Vainiutè [23]; Avdeev et al. [24]) show that immigration can lead to both positive and negative effects on the countries' demographic, economic, cultural and criminogenic situation depending on immigrants' education, age, gender and other characteristics. Even if immigration leads to positive transformation of the country, people's attitude towards immigrants can be negative. This can prevent successful integration of immigrants. For this reason, it is important to analyse not only the impact of immigration on countries' demography, economy, culture and other areas, but also to analyse individual attitudes towards immigration and immigrants. In this field studies are limited. The researchers commonly aim to identify differences of attitudes towards immigration in general depending on individuals' income and employment status, age, gender, race and other characteristics (Chvátalová [25]; Card et. al. [26]; Mayda [27]; Gurbanov et al. [28]; Mishra and Singhania [29]; Diaz et al. [30]; Butkus et al. [16]). Another group of researchers investigated migration as phenomena, migration flows and migration causes (Josifidis et al. [31]; Brown et. al. [32]; Afonso and Devitt [33]; Davidavičienè and Lolat [34]; Szarucki et. al. [35]; Iancu et al. [36] and etc.). There are also some studies that analyse demographic, economic, fiscal impact of immigration. However, we found only few studies that analysed people's attitudes towards immigration impact on countries' economy, culture, social cohesion (Finseras et. al. [37]; Tartakovsky and Walsh [38]), criminogenic situation (Ceobanu [39]) in the EU countries. In this regard, the aim of this research is to evaluate society's attitude towards immigration not just as to phenomenon in general, but in terms of immigration impact on country's economy, culture and criminogenic situation. In parallel, we are also interested in factors that shape these attitudes at personal level. This analysis also tends to find a link between macro level studies dealing with impact that immigration actually has and people's attitudes towards this impact.

The rest of the research is organised as follows: Section 2, that is based on the review of theoretical and empirical studies, classifies and discusses immigration consequences for host societies. Section 3 presents and explains the model of research. Research results and discussion is presented in Section 4 and Section 5 concludes the paper.

Conceptual framework of immigration consequences for host country. Local people's attitudes towards immigration can be explained using threat-benefit theoretical model. As noted by Tartakovsky Walsh [38], this model suggests that the local population perceives immigrants as both threatening and beneficial for the society. The model assumes that perceiving of particular immigrant group as threatening or beneficial for the society depends on opinions regarding immigration policy related to this immigrant group. The threat-benefit model has the constructivist nature. However, stereotypical nature approach states that immigration is related to negative consequences on local society. Individual-based economic arguments fail, not because of any materialist concerns, but because individuals vary on the fundamental value of tolerance (see Bordea et al. [40]; Goldstein and Peters [41]; Hainmueller et. al. [42]).

It is clear that immigration can lead to a multiple effect on the host country. The researchers in their analyses or theoretical debates often focus on the demographic, economic and fiscal impact of immigration on host society. Nevertheless, in some scientific articles there is mentioned social and cultural impact of immigration. Having in mind different classifications of immigration consequences for host societies, based on scientific sources there can be distinguished four main groups of them (Table 1).

It is indisputable that immigration affects host country's demographics. In countries with constantly growing, due to high birth rates, population this effect can be considered as negative. However, in countries where the population is decreasing immigration helps to solve depopulation problem, but this impact is inseparable from the assessment of economic and cultural impact. For example, despite the fact that immigration helps to solve depopulation problem this effect can be considered in society as 
М. Буткус, А. Мацюліте-Снікієн, К. Матузєвіцю, В. Давидович. Дослідження ставлення суспільства до наслідків імміграції на прикладі країн $€ С$

negative if it is achieved by sacrificing country's cultural identity, if threat-benefit balance of immigration is negative.

Table 1 - Classification of immigration consequences for host societies (own generalization)

\begin{tabular}{|c|c|c|}
\hline Impact & Main consequences & Authors \\
\hline Demographic & $\begin{array}{l}\text { 1) immigration increases the size of } \\
\text { population } \\
\text { 2) immigration changes population structure } \\
\text { by age and gender }\end{array}$ & $\begin{array}{l}\text { Zachariah et. al. [43]; Beaujot [44]; Coleman [45]; } \\
\text { Schaub et. al. [46]; Brown and Collopy [47]; Schaub } \\
\text { and Fletcher [48]; United Nations [49]; Weber [50] }\end{array}$ \\
\hline Economic-fiscal & $\begin{array}{l}\text { 1) immigration influences labour market } \\
\text { 2) immigration affects public finances } \\
\text { 3) immigration can boost or harm economic } \\
\text { growth }\end{array}$ & $\begin{array}{l}\text { Strielkowski and Gryshova [51]; Mayr [4]; Howland } \\
\text { and Nguyen [52]; Kerr and Kerr [7]; Švec [53]; Edo } \\
\text { [54]; Ortega and Verdugo [55]; Islam and Khan [56]; } \\
\text { Štreimikienè et. al. [57]; Bove and Elia [20]. }\end{array}$ \\
\hline Social & $\begin{array}{l}\text { 1) immigration can change criminogenic } \\
\text { situation } \\
\text { 2) immigration changes the level of public } \\
\text { goods consumption (public education, } \\
\text { personal social services) } \\
\text { 3) immigration can change health level and } \\
\text { level of health care expenditure }\end{array}$ & $\begin{array}{l}\text { Lee and Martinez [58]; Ceobanu [39]; Spenkuch [59]; } \\
\text { Wolff et al. [60]; Orchard et. al. [61]; Kofman et al. } \\
\text { [62]; George et al. [63]; Goldman et. al. [64]; Razum } \\
\text { and Wenner [65]. }\end{array}$ \\
\hline Cultural & $\begin{array}{l}\text { 1) immigration forms a multi-cultural } \\
\text { environment } \\
\text { 2) immigration can change host countries' } \\
\text { societies approaches towards discrimination } \\
\text { based on race, religion or gender }\end{array}$ & $\begin{array}{l}\text { Suarez-Orozco [66]; Niebuhr [67]; Tubadji and } \\
\text { Nijkamp [13]; Simionescu et. al. [68]; Byrne and } \\
\text { Dixon [14]; Waldron [69]. }\end{array}$ \\
\hline
\end{tabular}

In explaining economic impact of immigration, it should be noted that immigration can boost or reduce economic growth mainly by two channels: 1) accumulation of human capital; 2) investment in physical capital and its sectorial allocation. Immigrants may influence both - the deepening and the size of the human capital available in the receiving economy. However, this effect depends on the level of immigrants' knowledge and skills. An inflow of foreign workers can give rise to an upward aggregate labour demand curve and to an increase in the investments in physical capital that boosts host country's economy. On the other hand, immigration may influence not only the level of physical capital but also its sectorial allocation. This effect can be positive or negative. According to Carillo et. al. [70], inflows of high-skilled immigrants may cause an expansion of the efficient sectors, but inflows of low-skilled immigrants may draw capital to the less efficient sector causing a stagnation of the economy.

Immigrants also influence labour market mainly changing unemployment rate and wage level. In the short-run, immigration increases labour supply and causes unemployment and/or lower wages i.e. manifests crowding-out effect in labour market. On the other hand, as suggested by some authors (Carillo et. al. [70]; Daveri and Venturini [71]), this effect cannot occur since the labour market is mainly segmented. In a perfectly segmented labour market, immigrants take those jobs which are unattractive for native workers; as a consequence, there is no higher competition and no wage decreasing for natives (Carillo et. al. [70]). A similar approach is provided in OECD Economic Surveys [72]: in economy with strong regional unemployment rate contrasts, immigrants certainly show a "normal" market response to demand and supply for labour - they move quite quickly to where the demand is, and areas where unemployment is high have relatively low immigrant populations. Diaz et al. [30] showed that as unemployment increased and growth rate of real GDP decreased in Arizona over 2006 - 2009, attitudes toward illegal immigrants from Mexico became progressively more negative.

The fiscal impact of immigrants occurs as effect on inter-temporal fiscal balance. The fiscal impact of 
immigration is closely related to demographic impact. According to Mayr [4], immigration enlarges population and changes its age and/or gender composition and thus the tax base. Furthermore, immigration influences transfer payments due to a higher or lower tax comparing with natives. However, immigration effect on budget manifests not only by tax revenue, but also by public expenditures on immigrants' integration and social payments. As Kerr and Kerr [7] noted that the central question in this case is whether immigration burdens the host country's social benefits system, welfare services, education system, and health care sector more than is covered by the taxes paid by the immigrants. Kerr and Kerr [7], based on wild scope of retrospective studies, concluded that on average, immigrants appear to have a minor positive net fiscal effect on host countries. This is also confirmed by later studies. For example, Mayr [4] estimated positive overall fiscal effect of immigration on Austria's fiscal budget.

Based on retrospective research by Finseraas et. al. [37], we can state, that the majority of population believe that immigrants challenge their position in the labour market or impose a burden on public finances by increasing the proportion of the population that depends on provisions from the welfare state. However, the authors carried out a study using the European Social Survey data and found that individual attitudes toward immigrants' impact on economy depend on economic cycles and on proportion of foreign born people in the country.

Social impact of immigration on host societies in scientific literature is usually defined through the change of crime situation and the change level of public goods consumption (public education, personal social services, and public health services).

Regardless that crime has an impact on society's beliefs and attitudes (Blumer [73]), recent research has largely revised the grounding of realized immigrants' impact on crime. According to Ceobanu [39], because immigration increases country's population (mostly population of unmarried young males), it directly increase criminality and number of people in prisons. The reinforced belief that immigrants are the main causers for increased crime leads to that the blame for criminal behaviour falls directly on foreigners (Card et. al. [26]).

At the individual-level, a substantial body of literature has found that immigrants are less, not more, crime prone than their native-born counterparts (Bersani [74]; Bersani et. al. [75]). Similarly, the basic conclusion which suggests community-level studies on the relationship between immigration and crime is that larger immigrant populations do not correspond with higher rates of criminality (Lee and Martinez [58]; Lee et. al. [76]; Sampson et. al. [77]; Stowell and Martinez [78]; Martinez and Stowell [79]).

Immigration can increase overall demand for public education which causes the increase of government's education expenditure in short run. This is confirmed by some studies (Coen-Pirani [80]; George et al. [63]; Speciale [81]; Tanaka et. al. [82]). For example, Speciale [81] investigated the impact of immigration on public expenditures on education in EU-15 countries. Results of the study revealed that an increase in foreign population has a negative but small effect on these expenditures. However, in making generalized conclusions, the positive impact of educated persons on countries' economy in long run should be considered.

Immigration can increase overall demand for health services. In a society an approach dominated that providing health care for immigrants creates a public burden (RAND [82]). However, research revealed that the immigrants (especially illegal) contribute less to health care costs, because of lack of health insurance, but also use disproportionately fewer medical services in relation to their population share, likely because of their better relative health (Goldman et. al. [64]; Mohanty et al. [84]; George et al. [63]).

Discussing immigration impact on consumption of personal social services, it should be noted that there has been very little research investigating this relationship (George et al. [63]). Research which 
analysed migrants' use of social care and social services concluded their low levels of take-up (Kofman et al. [62]; Orchard et. al. [61]). Research in Scotland which covered 90 migrants and two focus groups, revealed that just little part of immigrants were using any social work services but were not aware of the services which they could access (George et al. [63]).

According to George et al.[63], UK estimates shows that total expenditure on education, health and personal social services accounts for 44 per cent of public services expenditure. Nevertheless, in proportional terms, average demand per adult for education, health and personal social services is estimated to be lower than for non-migrants.

In explaining cultural impact of immigration, it has to be noted, that immigration process inevitably changes the members of the dominate culture (Suarez-Orozco [66]). Large scale of immigration can change nutrition, entertainment, and consumption traditions of host countries' people. Furthermore, immigration can change the approaches of host countries' societies towards discrimination based on race, religion or gender.

So we can state that international migration has both direct and indirect effects on economic growth. Immigration impact on society can be controversial. Nevertheless, even if immigration leads to a positive transformation of the country, society's attitude towards immigration can be negative.

Variables, hypotheses and model. The results of theoretical and empirical studies on immigration show that positive/negative impact of immigration/immigrants is potentially related to the area of this impact and society's attitude towards this impact depends on many socio-economic characteristics at personal level. In accordance with previous studies concerning this topic, in this analysis binary logistic regression was chosen as the most suitable statistical tool for empirical estimation of societies' strata possessing different attitudes towards immigration impact and comparing them regarding area of the impact. ESS database was used as the source of raw data. The attitude towards immigration impact was originally in raw data measured in various Likert-type scales, ranging from 1-4 to 0-10 scales. To simplify interpretation, all the above mentioned scales are re-encoded into binary, using simple mathematical division. In cases when scales had an uneven number of answer possibilities, the "leftover value" in the neutral middle was counted as negative attitude. To this end, dependent variables, describing European peoples' attitude towards immigration impact, i.e. their positive or negative nature of answers to questions:

1. Do immigrants make country a better place to live? (Using answers to this question we identify overall or general societies' attitude toward immigration impact)

2. Does immigration have a positive impact on country's economy?

3. Do immigrants enrich country's culture?

4. Does immigration decrease crime? (Originally in the survey this question was formulated as "Do immigrants make country's crime problems worse". To have encoding parallel to other questions, i.e. positive nature of formulated question and thus to simplify analysis and interpretation formulation of this question was changed along with answers to it. Positive attitude was described as value "1" and negative one as "0".

The characteristics potentially describing society's strata with different attitude towards immigration impact, i.e. independent variables in the model, are presented in Table 2.

From theoretical point of view (Schweitzer et al. [85]; Mayda [27]; Hainmueller and Hiscox [86]; Facchini and Mayda [87]; Strielkowski and Sanderson [88]; Paas and Halapuu [89]; Murray and Marx [90]; Hatton [91]), we can predict possible impact of independent variables, i.e. characteristics describing particular society's stratum that has higher probability to possess positive attitude towards immigration impact (Table 2, third column). Nevertheless, we cannot hypothesise are there any 
differences in characteristics of society's strata that have positive attitude towards immigration impact on country's economy, culture or criminogenic situation.

Table 2 - Socio-economic characteristics (independent variables) of society's strata with different attitudes towards immigration impact (own formation)

\begin{tabular}{|c|c|c|}
\hline $\begin{array}{l}\text { Socio-economic } \\
\text { characteristicl } \\
\text { Variable name }\end{array}$ & Description of variable & $\begin{array}{l}\text { Characteristic of society's stratum } \\
\text { that has the highest probability to } \\
\text { possess positive attitude towards } \\
\text { immigration impact }\end{array}$ \\
\hline Education level & $\begin{array}{l}\text { Four dummy variables are assigned: "basic education", "high } \\
\text { school diploma", "vocational school diploma" and "higher } \\
\text { education". "Primary education" is chosen as benchmark } \\
\text { group. }\end{array}$ & $\begin{array}{l}\text { People with higher level of } \\
\text { education. }\end{array}$ \\
\hline Employment status & $\begin{array}{l}\text { We use two dummy variables: "people without job looking for } \\
\text { one" and "people who are neither working nor looking for a } \\
\text { job". "Working people" is chosen as benchmark group. }\end{array}$ & People who work. \\
\hline Insufficient income & $\begin{array}{l}\text { This variable is described only by the subjective opinion of } \\
\text { the respondents: people who answered they can manage (or } \\
\text { even manage well) with their income - "0" and people who } \\
\text { encounter difficulties managing with their family's income - } \\
\text { "1". }\end{array}$ & $\begin{array}{l}\text { People who are satisfied with their } \\
\text { family's financial situation. }\end{array}$ \\
\hline Female & Coded into binary form: male - "0" and female - "1" & Females. \\
\hline Marital status & $\begin{array}{l}\text { Consists of three dummy variables: "divorced", "widowed" } \\
\text { and "never married" people. "Married people" is chosen as } \\
\text { benchmark group. }\end{array}$ & People who are married. \\
\hline Children & Families having children - "1" or not - "0". & Families without children. \\
\hline Religious & $\begin{array}{l}\text { People who consider themselves religious - "1" and people } \\
\text { not so - "0" }\end{array}$ & $\begin{array}{l}\text { People who consider themselves } \\
\text { religious. }\end{array}$ \\
\hline Countryside & $\begin{array}{l}\text { People who live in cities encoded as "0" and people living in } \\
\text { countryside as "1" }\end{array}$ & People living in cities. \\
\hline $\begin{array}{l}\text { Central/Western } \\
\text { Europe }\end{array}$ & $\begin{array}{l}\text { Citizens of Northern and Eastern European countries are } \\
\text { encoded as "0", people of Central and Western European } \\
\text { countries as "1", both representing about half of the whole } \\
\text { sample. }\end{array}$ & $\begin{array}{l}\text { Natives from Central and Western } \\
\text { European countries. }\end{array}$ \\
\hline Age & $\begin{array}{l}\text { Three dummy variables are assigned to following groups } \\
\text { "from } 21 \text { to } 40 \text { ", "from } 41 \text { to } 60 \text { " and " } 61 \text { and above". "Up to } \\
20 \text { " is chosen as benchmark group. }\end{array}$ & Younger people. \\
\hline Lack of safety & $\begin{array}{l}\text { "Feeling safe walking home after dark" assigned to "0" and } \\
\text { the opposite of that to "1". }\end{array}$ & People feeling safe. \\
\hline
\end{tabular}

The regression model for empirical estimations is composed as follows:

$$
P(Y)=\frac{e^{\left(\beta_{0}+\beta_{1} X_{1}+\cdots+\beta_{11} X_{11}+\varepsilon\right)}}{1+e^{\left(\beta_{0}+\beta_{1} X_{1}+\cdots+\beta_{11} X_{11}+\varepsilon\right)}}
$$

where $P(Y)$ is a probability of occurrence of a positive attitude over negative attitude towards immigrants' impact, as negative attitude in the model is considered as the benchmark value. $\mathrm{x}_{1}, \ldots, \mathrm{x}_{11}$ marks all eleven independent variables, i.e. characteristics, in the model starting from education level. $\beta_{1}, \ldots, \beta_{11}$ as usual marks the regression coefficients, giving information how strongly and in which direction independent variables affect the odds ratio of the dependent variable.

We do not separately analyse society's attitudes towards social impact of immigration because this 
impact is reflected through general impact. And there is a lack of statistics for the research of attitudes towards demographic impact of immigration.

Estimation results and discussion. On the whole, ESS database consists of about 47 thousand respondents. Rather scarce is data about marital and work statuses (data about these factors is available for a bit more than $60 \%$ of all questioned respondents). Incomplete data (nevertheless, for some of variables we had data from almost $99.9 \%$ of respondents) reduces sample size for our research to about 26.7 thousand. Fig.1 presents distribution of positive/negative attitudes toward immigration impact on different areas.

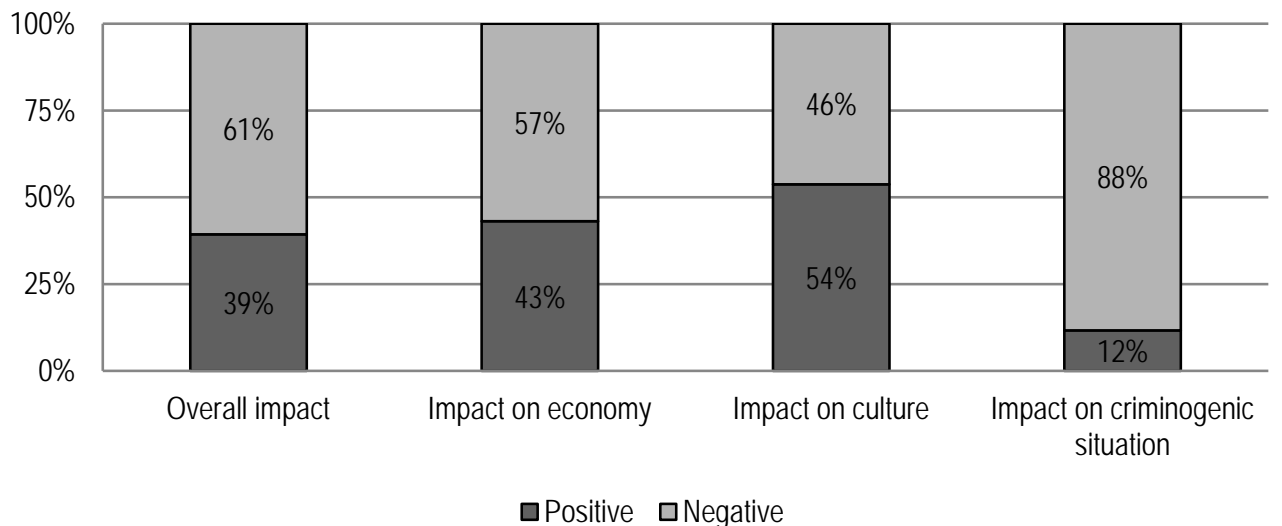

Figure 1 - Society's attitude towards immigration impact on different areas (own calculations)

As it can be seen, 57 per cent of respondents have negative attitudes towards immigrants' impact on economy. Meanwhile, retrospective researches show that immigrants' impact on economy is mainly positive (Mayr [4]; Howland and Nguyen [52]; Tubadji and Nijkamp [13]).

Research conducted in the US shows positive immigration impact on culture, but such studies at the EU level have not been detected. So, we cannot compare immigration impact on culture with the attitudes towards this type of impact.

Respondents' attitudes towards immigrants' impact on crime level do not reflect the actual situation. As mentioned before, larger immigrant populations are not associated with higher rates of crime in the aggregate (Lee and Martinez [58]; Lee et. al. [76]; Sampson et. al. [77]; Stowell and Martinez [78]; Martinez and Stowell [79]).

The estimation results of binary logistic regression model linking factors with odds ratios of the positive attitude towards immigration impact on different areas are presented in Annex 1. All four estimated models are not particularly descriptive, the pseudo $\mathrm{R}^{2}$ is about 0.1 , but according to goodness-to-fit test it is "better than nothing at all". To test whether the models fit the data, HosmerLemeshow test was employed. The model fits well if test statistic produces a non-significant chi-square value. In case of our models, the p-value of the chi-square was from 0.134 to 0.820 indicating chi-square value as insignificant by all commonly used confidence levels (lowest of them being $p<0.1$ ).

Most influential characteristics through the models in terms of how many times they appeared to be significant, together with whether they increase or decrease probability for society to have positive attitude toward immigration impact on different areas, i.e. characteristics of society's stratum that possess positive attitude, can be found in Table 3 . 
Розділ 4 Проблеми управління інноваційним розвитком

Table 3 - Effects of personal characteristics in the models (own conclusions)

\begin{tabular}{|l|c|c|c|c|}
\hline \multirow{2}{*}{ Characteristics } & \multicolumn{3}{|c|}{ Dependent variable: societies' attitude towards immigration impact } \\
\cline { 2 - 5 } & in general & on economy & on culture & on crime \\
\hline Insufficient income & reduces & reduces & reduces & No impact \\
\hline Higher education & increases & increases & increases & increases \\
\hline $\begin{array}{l}\text { Central/Western } \\
\text { Europe }\end{array}$ & No impact & increases & increases & No impact \\
\hline Being female & No impact & reduces & increases & No impact \\
\hline Lack of safety & reduces & reduces & reduces & No impact \\
\hline $\begin{array}{l}\text { Inactive in labour } \\
\text { market }\end{array}$ & increases & No impact & No impact & increases \\
\hline Older age & No impact & reduces & No impact & No impact \\
\hline
\end{tabular}

Reduces - society's characteristic that reduces probability to possess positive attitude towards immigration impact on particular area, i.e. characterises society's stratum that possesses negative attitude towards immigration impact on particular area.

Increases - society's characteristic that increases probability to possess positive attitude towards immigration impact on particular area, i.e. characterises society's stratum that possesses positive attitude towards immigration impact on particular area

No impact - society's characteristic that has no effect on attitude towards immigration impact on particular area

We found very clear statistical evidence, that insufficient income forms society's stratum where it is more likely to find people possessing negative attitude towards immigration impact on all areas except crime. In a group of people who can manage (or even manage well) with their income it is 1.6 times more likely to find those who have positive attitude toward immigration impact in general, it is 1.7 times more likely to find those who have positive attitude toward immigration impact on economy and it is 1.5 times more likely to find those who think that immigration enriches country's culture than in group of those with insufficient income. Negative attitude towards immigration in the group of people who receive less income is related to their concern that immigration is a threat to their source of income. Immigrants are considered as potential causes for increasing competition, inducing downward pressure on natives' incomes, and situation of uncertainty.

It seems that more educated societies assess immigration impact more positively. The same tendency is observed through all analysed impact areas. It is also very clear that with higher level of education the probability to possess positive attitude towards immigration impact increases, for example for a person with a high school diploma are 1.8, with a vocational school diploma are 4.5 and with a higher education are 6.5times more likely to possess positive attitude towards immigration impact on economy compared with those having primary education. Higher levels of education enable people to evaluate objectively immigration impact. Opinion of more educated people is built on rationality and higher level of awareness not on emotions or media. Less educated natives will suffer from competition with immigrants in the labour market so their opinion might be influenced by this threat.

Estimation results show that societies of Western and Central Europe countries have slightly more positive attitude towards immigration impact on country's economy and culture, i.e. it is 1.6 and 1.3 times more likely to find a person that has positive attitude toward immigration impact on countries' economy and culture respectively in those societies compared with ones in Northern and Eastern European countries. Western countries are more open to other cultures and up to refugee crisis in 2015 when rising numbers of illegal migrants arrived in the EU, immigration was considered as source of cheap labour force and solution for ageing societies. 

імміграції на прикладі країн $€ C$

Female compared with male have more positive attitude towards immigration impact on country's culture, but male compared with female possess more positive attitude toward economic impact of immigration. Women seem to be more concerned than men about the social integration and economic assimilation of immigrants, also women more often face with discrimination and thus are more prone towards people in the same situation (Hughes and Tuch [92]; Amuedo-Dorantes and Puttitanun [93]).

It is clear that safety is one of main factors that affects people attitudes towards immigration impact. Lack of safety increases twice the probability to possess negative attitude towards immigration impact on economy and culture, so we have much more chance to find positively set people in societies that feel safe. If people feel unsafe of their neighbourhood, they might accuse immigrants for criminal activity and violence.

It seems that people who are inactive in labour market possess more positive attitude towards overall immigration impact and impact on criminogenic situation. Lower competition in labour market might form this positive attitude.

We did not find any significant differences in attitudes between age groups, except in case of attitudes towards immigration impact on economy. For a person from 21 to 40 years old it is 1.6 and from 41 and above it is 2.2 times more likely to possess negative attitude towards immigration impact on economy compared with those 20 years old and younger. It could be that elder individuals spend their whole lives with less liberal society so it influenced their negative attitudes towards immigration comparing with younger individuals.

Our estimation results show that personal characteristics, such as marital status, religiosity, place of residence and children have no effect, i.e. we cannot find significant difference in attitudes among people in terms of these characteristics.

All estimation results of the model are shown in Table 4.

Table 1 - Estimation results of the models

\begin{tabular}{|c|c|c|c|c|c|c|c|c|}
\hline \multirow{3}{*}{$\begin{array}{c}\text { Societies' } \\
\text { characteristics in } \\
\text { the model }\end{array}$} & \multicolumn{8}{|c|}{ Dependent variable: societies' attitude towards immigration impact } \\
\hline & \multicolumn{2}{|c|}{ in general } & \multicolumn{2}{|c|}{ on economy } & \multicolumn{2}{|c|}{ on culture } & \multicolumn{2}{|c|}{ on crime } \\
\hline & $\begin{array}{l}\text { Estimated } \beta \\
\text { coefficient } \\
\text { (B) }\end{array}$ & $\begin{array}{l}\text { Exp } \\
\text { (B) }\end{array}$ & $\begin{array}{l}\text { Estimated } \beta \\
\text { coeff-icient } \\
\text { (B) }\end{array}$ & $\begin{array}{l}\text { Exp } \\
\text { (B) }\end{array}$ & $\begin{array}{l}\text { Estimated } \beta \\
\text { coefficient } \\
\text { (B) }\end{array}$ & $\begin{array}{l}\text { Exp } \\
\text { (B) }\end{array}$ & $\begin{array}{l}\text { Estimated } \beta \\
\text { coeff-icient } \\
\text { (B) }\end{array}$ & $\begin{array}{l}\text { Exp } \\
\text { (B) }\end{array}$ \\
\hline 1 & 2 & 3 & 4 & 5 & 6 & 7 & 8 & 9 \\
\hline Constant & -0.294 & 0.745 & -0.109 & 0.897 & -0.443 & 0.642 & $-3.382^{\star \star \star}$ & 0.034 \\
\hline \multicolumn{9}{|l|}{ Education level } \\
\hline Basic education & $0.601^{*}$ & 1.824 & 0.756 ** & 2.130 & 0.313 & 1.368 & $1.159^{*}$ & 3.185 \\
\hline $\begin{array}{r}\text { High school } \\
\text { diploma }\end{array}$ & 0.249 & 1.283 & $1.039 * * \star$ & 2.825 & $0.504^{*}$ & 1.655 & $1.293^{\star \star}$ & 3.645 \\
\hline $\begin{array}{r}\text { Vocational school } \\
\text { diploma }\end{array}$ & $0.820^{\star *}$ & 2.271 & $1.511^{\star \star \star}$ & 4.533 & $1.051^{\star \star \star}$ & 2.860 & $2.116^{\star \star \star}$ & 8.302 \\
\hline Higher education & $1.022^{\star \star \star}$ & 2.778 & $1.878^{\star \star \star}$ & 6.542 & $1.373^{\star \star \star}$ & 3.946 & $1.157^{*}$ & 3.180 \\
\hline \multicolumn{9}{|l|}{ Employment status } \\
\hline $\begin{array}{r}\text { Jobless looking for } \\
\text { a job }\end{array}$ & 0.002 & 1.002 & 0.032 & 1.032 & 0.125 & 1.133 & 0.444 & 1.558 \\
\hline $\begin{array}{r}\text { Jobless not looking } \\
\text { for a job }\end{array}$ & $0.329^{\star *}$ & 1.389 & 0.064 & 1.066 & $0.263^{*}$ & 1.300 & $0.493^{\star \star}$ & 1.638 \\
\hline Insufficient income & $-0.449 * \star$ & 0.638 & $-0.551^{\star \star \star}$ & 0.576 & $-0.434^{\star \star}$ & 0.648 & 0.186 & 1.204 \\
\hline Female & 0.175 & 1.192 & $-0.269^{* *}$ & 0.764 & $0.345^{\star \star \star}$ & 1.412 & 0.110 & 1.117 \\
\hline \multicolumn{9}{|l|}{ Marital status } \\
\hline Divorced & $-0.779^{\star}$ & 0.459 & -0.412 & 0.662 & -0.433 & 0.649 & -0.154 & 0.857 \\
\hline Widowed & $-1.003^{\star \star}$ & 0.367 & -0.345 & 0.708 & -0.331 & 0.718 & -0.577 & 0.562 \\
\hline Single & $-0.699^{*}$ & 0.497 & $-0.695^{\star}$ & 0.499 & -0.164 & 0.848 & $-0.940^{*}$ & 0.391 \\
\hline
\end{tabular}




\begin{tabular}{|c|c|c|c|c|c|c|c|c|}
\hline 1 & 2 & 3 & 4 & 5 & 6 & 7 & 8 & 9 \\
\hline Children & 0.322 & 1.380 & -0.035 & 0.966 & $0.324^{*}$ & 1.383 & $0.560^{*}$ & 1.751 \\
\hline Religious & 0.076 & 1.079 & 0.069 & 1.071 & 0.108 & 1.114 & 0.104 & 1.109 \\
\hline Countryside & -0.216 & 0.806 & -0.167 & 0.846 & $-0.262^{*}$ & 0.770 & 0.131 & 1.140 \\
\hline $\begin{array}{l}\text { Central/Western } \\
\text { Europe }\end{array}$ & -0.106 & 0.899 & $0.465^{\star \star \star}$ & 1.592 & $0.260^{\star *}$ & 1.297 & -0.021 & 0.980 \\
\hline Age & & & & & & & & \\
\hline from 21 to 40 & -0.048 & 0.953 & $-0.457^{\star \star}$ & 0.633 & -0.099 & 0.906 & -0.239 & 0.787 \\
\hline from 41 to 60 & 0.187 & 1.205 & $-0.724^{\star \star \star}$ & 0.458 & 0.198 & 1.220 & -0.566 & 0.568 \\
\hline 61 and above & -0.041 & 0.960 & $-0.783^{\star \star \star}$ & 0.457 & 0.005 & 1.005 & -0.045 & 0.956 \\
\hline Lack of safety & $-0.678^{\star \star \star}$ & 0.508 & 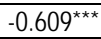 & 0.544 & $-0.896^{\star \star \star}$ & 0.408 & -0.014 & 0.986 \\
\hline $\mathrm{N}$ & \multicolumn{2}{|c|}{26436} & \multicolumn{2}{|c|}{25951} & \multicolumn{2}{|c|}{27571} & \multicolumn{2}{|c|}{26936} \\
\hline -2 Log likelihood & \multicolumn{2}{|c|}{1633.4} & \multicolumn{2}{|c|}{1653.3} & \multicolumn{2}{|c|}{1614.5} & \multicolumn{2}{|c|}{830.8} \\
\hline \multicolumn{9}{|l|}{ Pseudo $\mathrm{R}^{2}$} \\
\hline Cox\&Snell & \multicolumn{2}{|c|}{0.069} & \multicolumn{2}{|c|}{0.093} & \multicolumn{2}{|c|}{0.093} & \multicolumn{2}{|c|}{0.030} \\
\hline Negelkerke & \multicolumn{2}{|c|}{0.092} & \multicolumn{2}{|c|}{0.124} & \multicolumn{2}{|c|}{0.125} & \multicolumn{2}{|c|}{0.062} \\
\hline \multicolumn{9}{|l|}{$\begin{array}{l}\text { Hosmer and } \\
\text { Lemeshow test }\end{array}$} \\
\hline$x^{2}$ & \multicolumn{2}{|c|}{13.665} & \multicolumn{2}{|c|}{10.238} & \multicolumn{2}{|c|}{5.534} & \multicolumn{2}{|c|}{4.392} \\
\hline$p$-value & \multicolumn{2}{|c|}{0.134} & \multicolumn{2}{|c|}{0.249} & \multicolumn{2}{|c|}{0.699} & \multicolumn{2}{|c|}{0.820} \\
\hline
\end{tabular}

* indicates significance at the 10 percent level ** indicates significance at the 5 percent level *** indicates significance at the 1 percent level

Conclusions and directions of futher researches. The growing number of immigrants to the EU influences increasing interest in the issue about immigration impact on various areas of society: economics, culture, social situation. Scientific literature analysis shows that immigration leads to a multiple effects on host country. Considering that immigration has very controversial impact on host country and society it is very important to analyse society's attitudes towards immigration because this can help for better integration of immigrants because society's attitude towards immigration impact can differ from actual impact.

Conducted research shows that insufficient income and lack of safety reduce probability to possess positive attitude towards immigration impact in general. However, higher education and being inactive in labour market increase positive attitude. Region of EU, gender and age have no impact. Analysing attitude towards impact on economy, it can be stated that insufficient income, being female, lack of safety and elder age increase probability to possess negative attitude; meanwhile, higher education and origin from Central and Western Europe increase probability to possess positive attitude towards immigration impact on economy. Society's attitude towards immigration impact on culture is negatively influenced by insufficient income and lack of safety, positively - by higher education, citizenship of Central and Western Europe countries and being female. Position in labour market also age have no effect on attitude towards immigration impact on culture. We did not find significant differences in attitudes towards immigration impact on crimes among people, who get different income, belong to Central, Western or Northern and Eastern Europe, between gender and age groups, feeling about safety. Meanwhile, higher education and being inactive in labour market increase probability to possess positive attitude towards immigration impact on crimes.

It can be stated that retrospective researches show that immigration has positive impact on host economy through accumulation of human capital and investment in physical capital; meanwhile, majority of respondents have negative attitude towards immigration impact on economy.

Cultural impact of immigration is explained via changes of traditions, entertainments and even 
nutrition but researches are mainly conducted in the US and show positive immigration impact on culture, but such studies at the EU level have not been detected. So, we cannot compare immigration impact on culture with the attitudes towards this type of impact based on European Social Survey data.

Scientific researches show that larger immigrant populations are not associated with higher rates of crime so we can state that respondents' attitudes towards immigrants' impact on crime do not reflect the actual situation.

Having in mind the above mentioned, we can conclude that society's stratum which concentrates people with negative attitude towards immigration impact is characterised by insufficient income, low level of education, lack of safety, activity in labour market and old age. We can distinguish estimation of attitudes towards immigration impact on crime from the rest of the analysis, because in this case negative opinions were mostly unanimous, i.e. just a few personal characteristics led to differences in attitudes.

1. Smith, P.J., \& Edmondson, B. (1997). The New Americans: Economic, Demographic, and Fiscal Effect of Immigration. Washington: National Academy Press.

2. Auerbach, A. J., \& Oreopoulos, P. (1999). Analyzing the fiscal impact of US immigration. American Economic Review, 89(2), 176-180. doi: 10.1257/aer.89.2.176

3. Lee, R., \& Miller, T. (2000). Immigration, Social Security, and Broader Fiscal Impacts. New Issues in Immigration, 90 (2), 350-354. doi: 10.1257/aer.90.2.350.

4. Mayr, K. (2005). The Fiscal Impact of Immigrants in Austria - A Generational Accounting Analysis. Empirica, 32, 181216. doi: $10.1007 / \mathrm{s} 10663-005-1758-3$.

5. Jiroudkova, A., Rovna, L.A., Strielkowski, W., Slosarcik, I. (2015). EU Accession, Transition and Further Integration for the Countries of Central and Eastern Europe. Economics \& Sociology, 8(2), 11-14. doi:10.14254/2071-789x.2015/8-2/1.

6. Simionescu, M., Ciuiu, D., Bilan, Y., Strielkowski, W. (2016). GDP and Net Migration in Some Eastern and South-Eastern Countries of Europe. A Panel Data and Bayesian Approach. Montenegrin Journal of Economics, 12(2),161-175 doi:10.14254/1800-5845.2016/12-1/10.

7. Kerr, P.S., 7 Kerr, R.W. (2011). Economic Impact of Immigration: A Survey. Harvard Business School Working Paper, 09-013.

8. Hinojosa-Ojeda, R. (2013). The Costs and Benefits of Immigration Enforcement. James A. Baker III Institute for Public Policy Rice University, Latin America Initiative Immigration Research Project Working Paper.

9. Berzinskiene, D., Butkus, M., \& Matuzeviciute, K. (2014). Modelling of the Impact of Emigrants' Qualification Structure on the National Economic Growth: the Case of Lithuania. Engineering Economics, 25(3), 333-340. doi: 10.5755/j01.ee.25.3.5247.

10. Docquier, F., Ozden, C.., \& Peri, G. (2014). The labour market effects of immigration and emigration in OECD countries. The Economic Journal, 124(579), 1106-1145. doi: 10.1111/ecoj.12077.

11. Strielkowski, W., Tumanyan, Y., Kalyugina, S. (2016). Labour Market Inclusion of International Protection Applicants and Beneficiaries. Economics and Sociology, 9(2), 293-302. doi: 10.14254/2071-789X.2016/9-2/20.

12. Metelski, D., \& Mihi-Ramirez, A. (2015). The Economic Impact of Remittances and Foreign Trade on Migration. GrangerCausality approach. Engineering Economics, 26(4), 364-372. doi: 10.5755/j01.ee.26.4.12464.

13. Tubadji, A., \& Nijkamp, P. (2015). Cultural Gravity Effects among Migrants: A Comparative Analysis of the EU15. Economic Geography, 91(3), 343-380. doi: 10.1111/ecge.12088.

14. Byrne, J., \& Dixon, C.G. (2016). Just Not Like Us: The Interactive Impact of Dimensions of Identity and Race in Attitudes towards Immigration. Social Sciences, 59(5), 1-22. doi: 10.3390/socsci5040059.

15. Strielkowski, W. S., Bilan, Y. B., \& Kalyugina, S. K. (2016). Social and public dimensions of international migration: a comparative study of Turkey and Ukraine. Novedades en Población, 12(24), 156-167.

16. Butkus, M., Mačiulytè-Šniukienè, A., Davidavičienè, V., \& Matuzevičiūtè, K. (2016). Factors influencing society's attitudes towards internal and external EU immigrants. Filosofija. Sociologija, 27(4), 292-303.

17. Butkus, M., Mačiulytè-Šniukienè, A., \& Matuzevičiūtè, K. (2016). Socio-demographic factors influencing attitude towards refugees: an analysis of data from European social survey. Globalization and its socio-economic consequences: $16^{\text {th }}$ international scientific conference, 5th-6th October 2016, Rajecke Teplice, Slovak Republic: proceedings. Part I. Zilina : University of Zilina, 286-294.

18. Kushnirovich, N. (2016). Immigrant investors in financial markets: modes of financial behavior. Journal of Business Economics and Management, 17(6), 992-1006. doi: 10.3846/16111699.2016.1171253.

19. Sánchez-Pagés, S., \& García, S.Á. (2016). Immigration, Conflict, and Redistribution. The Scandinavian Journal of Economics, 118(3), 557-593. doi: 10.1111/sjoe.12158.

20. Bove, V., \& Elia, L. (2017). Migration, Diversity, and Economic Growth. World Development, 89, 227-239. doi: 
10.1016/j.worlddev.2016.08.012.

21. Lincényi, M. (2017). Entrepreneurship ecosystem facets: the European migrant crisis and public opinion in Slovakia. Entrepreneurship and Sustainability Issues, 5(2), 357-367. doi: 10.9770/jesi.2017.5.2(14).

22. Kordík, M. \& Kurilovská, L. (2017). Protection of the national financial system from the money laundering and terrorism financing. Entrepreneurship and Sustainability Issues, 5(2), 243-262. doi: 10.9770/jesi.2017.5.2(7).

23. Beinoravičius, D., \& Vainiutè, M. (2017). The management of terrorism roots as a prerequisite for successful fight against terrorism. Journal of Security and Sustainability Issues, 7(2): 193-202. doi: 10.9770/jssi.2017.7.2(2).

24. Avdeev, V. Avdeeva, O., Rozenko, S., Znamerovskiy, E. \& Kiselyov, E. (2017). Crime of the Terrorist Character and Extremist Orientation in the Russian Federation: State and Measures of Counteraction. Journal of Security and Sustainability Issues, 7(2), 359-367. doi: 10.9770/jssi.2017.7.2(15).

25. Chvátalová, I. (2016). Social policy in the European Union. Czech Journal of Social Sciences, Business and Economics, 5(1), 37-41. doi: 10.24984/cjssbe.2016.5.1.4.

26. Card, D., Dustmann, C., \& Preston, I. (2005). Understanding attitudes to immigration: The migration and minority module of the first European Social Survey. University College London, Centre for Research and Analysis of Migration Discussion Paper $03 / 05$.

27. Mayda, M.A. (2006). Who Is Against Immigration? A Cross-Country Investigation of Individual Attitudes toward Immigrants. Review of Economics and Statistics, 88(3), 510-530

28. Gurbanov, R., Bilan, Y., \& Strielkowski, W. (2015). Economic advantages and disadvantages of Turkish EU accession. Montenegrin Journal of Economics, 11(2), 7-30. doi: 10.14254/1800-5845.2015/11-2/1.

29. Mishra, U.S., Singhania, D. (2014). Contrasting the Levels of Poverty against the Burden of Poverty: An Indian Case. International Economics Letters, 3(2), 26-35. doi: 10.24984/iel.2014.3.2.1.

30. Diaz, P., Saenz, S.D., \& Kwan, S.Y.V. (2011). Economic dynamics and changes in attitudes towards undocumented Mexican immigrants in Arizona. Analyses of Social Issues and Public Policy, 11, 300-313. doi: 10.1111/j.1530-2415.2011.01255.x

31. Josifidis, K., Supic, N., Pucar, B.E., \& Srdic, S. (2014). Labour migration flows: EU8+2 vs EU-15. Journal of Business Economics and Management, 15(1), 41-55. doi: 10.3846/16111699.2013.841283.

32. Brown, A., Msoka, C., \& Dankoco I. (2015). A refugee in my own country: Evictions or property rights in the urban informal economy? Urban Studies, 52(12), 2234-2249. doi: 10.1177/0042098014544758

33. Sanderson, M., Strielkowski, W., \& Hlustikova, K. (2014). Ukrainian Labour Migration in the Czech Republic: Brain-Drain and the Existence of Structural Channels. Politická ekonomie, 62(4), 542-559. doi: 10.18267/j.polek.968.

34. Davidavičienė, V., \& Lolat, I. (2016). Migrant entrepreneurship in Europe: challenges and opportunities. The 9th International Scientific Conference "Business and Management 2016", 1-14.

35. Szarucki, M., Brzozowski, J., \& Stankevičienè, J. (2016). Determinants of self-employment among Polish and Romanian immigrants in Germany. Journal of Business Economics and Management, 17(4), 598-612. doi: 10.3846/16111699.2016.1202313.

36. Iancu, N., Badulescu, A., Urziceanu, R.M., lancu, E.A., \& Simut, R. (2017). The use of the gravity model in forecasting the flows of emigrants in EU countries. Technological and Economic Development of Economy, 23(2), 392-409. doi: 10.3846/20294913.2016.1213194.

37. Finseraas, H., Pedersen, W.A., \& Bay, A.H. (2016). When the Going Gets Tough: The Differential Impact of National Unemployment on the Perceived Threats of Immigration. Political Studies, 64(1), 60-73. doi: 10.1111/1467-9248.12162.

38. Tartakovsky, E., \& Walsh, D.S. (2016). Testing a New Theoretical Model for Attitudes Toward Immigrants: The Case of Social Workers' Attitudes Toward Asylum Seekers in Israel. Journal of Cross-Cultural Psychology, 47(1), 72-96. doi: 10.1177/0022022115613860.

39. Ceobanu, M.A. (2011). Usual suspects? Public view about immigrants' impact on crime in European countries. International Journal of Comparative Sociology, 52(1-2), 114-131. doi: 10.1177/0020715210377154.

40. Bordea, E., Manea, M., Pelligrini, A. (2017). Unemployment and coping with stress, anxiety, and depression. Czech Journal of Social Sciences, Business and Economics, 6(2), 6-14. doi: 10.24984/cjssbe.2017.6.2.1.

41. Goldstein, L.J., \& Peters, E.M. (2014). Nativism or Economic Threat: Attitudes Towards Immigrants During the Great Recession. International Interactions, 40, 376-401. doi: 10.1080/03050629.2014.899219.

42. Hainmueller, J., Hiscox, J.M., \& Margalit, Y. (2015). Do Concerns about Labour Market Competition Shape Attitudes Toward Immigration? New Evidence. Journal of International Economics, 97(1), 193-207. doi: 10.1016/j.jinteco.2014.12.010.

43. Zachariah, C.K., Mathew, Th.E., \& Rajan, S.I. (2001). Social, Economic and Demographic Consequences of Migration on Kerala. International Migration, 39(2), 43-71. doi: 10.1111/1468-2435.00149.

44. Beaujot, R. (2002). Effect of Immigration on Demographic Structure. University of Western Ontario Population Studies Centre Discussion Papers Series, 10-1-2002, 6, 9, Article 1.

45. Coleman, D. (2008). The demographic effects of international migration in Europe. Oxford Review of Economic Policy, 24(3), 452-476. doi: 10.1093/oxrep/grn027.

46. Schaub, M., Jakober, H., \& Stauber, W. (2013). Strong contribution of immigration to local population regulation: evidence from a migratory passerine. Ecology, 94, 1828-1838. doi: 10.1890/12-1395.1.

47. Brown, L.J., \& Collopy, W.M. (2013). Immigration stabilizes a population of threatened cavity-nesting raptors despite 
possibility of nest site imprinting. Journal of Avian Biology, 44(2), 141-148. doi: 10.1111/j.1600-048X.2012.05728.x.

48. Schaub, M., \& Fletcher, D. (2015). Estimating immigration using a Bayesian integrated population model: choice of parametrization and priors. Environmental and Ecological Statistics, 22(3), 535-549. doi: 10.1007/s10651-015-0309-8.

49. United Nations. (2015). International Migration Report 2015, ST/ESA/SER.A/375. UN: New York.

50. Weber, H. (2015). Could Immigration Prevent Population Decline? The Demographic Prospects of Germany Revisited. Comparative Population Studies, 40(2), 165-190.

51. Strielkowski, W., \& Gryshova, I. Y. (2016). Ukrainian labour migration in the Czech Republic. Scientific Bulleting of Polissia, 4(8), 224-231.

52. Howland, M., \& Nguyen, D.B.L. (2009). The Impact of Immigration on Computer Manufacturing in the 1990s. Economic Development Quarterly, 23(1), 60-70. doi: 10.1177/0891242408327453.

53. Švec. O. (2013). Labour migration in the EU: an empirical evidence. International Economics Letters, 2(1),15-25.

54. Edo, A. (2013). The Impact of Immigration on Native Wages and Employment. Documents de travail du Centre d'Economie de la Sorbonne 2013.64

55. Ortega, J., \& Verdugo G. (2014). The impact of immigration on the French labor market: why so different? Labour Economics, 29, 14-27. doi: 10.1016/j.labeco.2014.05.002.

56. Islam, F., \& Khan, S. (2015). The long run impact of immigration on labor market in an advanced economy. International Journal of Social Economics, 42(4), 356-367. doi: 10.1108/IJSE-12-2013-0291.

57. Štreimikiené, D., Strielkowski, W., Bilan, Y., \& Mikalauskas, I. (2016). Energy dependency and sustainable regional development in the Baltic states: A review. Geographica Pannonica, 20(2), 79-87. doi: 10.5937/GeoPan1602079S.

58. Lee, T.M., \& Martinez Jr., R. (2002). Social Disorganization Revisited: Mapping the recent immigration and Black Homicide Relationship in Northern Miami. Sociological Focus, 35, 363-380. doi: 10.1080/00380237.2002.10570709.

59. Spenkuch, L.J. (2014). Understanding the Impact of Immigration on Crime. American Law and Economics Review, 16(1) 177-219. doi: 10.1093/aler/aht017.

60. Wolff, T.K., Baglivio, T.M., Intravia, J., \& Piquero, R.A. (2015). The protective impact of immigrant concentration on juvenile recidivism: A statewide analysis of youth offenders. Journal of Criminal Justice, 43(6), 522-531. doi: 10.1016/j.jcrimjus.2015.05.004.

61. Orchard, P., Szymanski, A., \& Vlahova, N. (2007). A Community Profile of EU8 Migrants in Edinburgh and an evaluation of their access to key services. Scottish Government Social Research Report.

62. Kofman, E., Lukes, S., D'angelo, A., \& Montagna, N. (2009). The equality implications of being a migrant in Britain. Equality and Human Rights Commission Research Report 19.

63. George, A., Meadows, P., Metcalf, H., \& Rolfe, H. (2011). Impact of migration on the consumption of education and children's services and the consumption of health services, social care and social services. National Institute of Economic and Social Research paper.

64. Goldman, P.D., Smith, P.J., \& Sood, N. (2006). Immigrants And The Cost Of Medical Care. Health Affairs, 25(6), 17001711. doi: $10.1377 /$ hlthaff.25.6.1700.

65. Razum, O., \& Wenner, J. (2016). Social and health epidemiology of immigrants in Germany: past, present and future. Public Health Reviews, 37(40), 1-17. doi: 10.1186/s40985-016-0019-2.

66. Suarez-Orozco, M.M. (2001). Global Shifts: U.S. Immigration and the Cultural Impact of Demographic Change. In Seismic Shifts: The Economic Impact of Demographic Change, ed. Jane S. Little and Robert K. Triest, 179-188. Boston: Federal Reserve Bank of Boston Conference Series No. 46

67. Niebuhr, A. (2009). Migration and innovation: Does cultural diversity matter for regional R\&D activity? Papers in Regional Science, 89(3), 563-585. doi: 10.1111/j.1435-5957.2009.00271.x.

68. Simionescu, M., Strielkowski, W., \& Kalyugina, S. (2017). The impact of Brexit on labour migration and labour markets in the United Kingdom and the EU. Terra Economicus, 15(1), 148-156. doi: 10.18522/2073-6606-2017-15-1-148-156.

69. Waldron, J. (2016). What Respects is Owed to Illusions About Immigration and Culture? NYU School of Low, Public Law Research Paper 16-49.

70. Carillo, R.M., Quintieri, B., \& Vinci, P.C. (1999). Causes and Economic Effects of Migration Flows - an Overview. Labour, 13(3), 587-602. doi: 10.1111/1467-9914.00107.

71. Daveri, F., \& Venturini, A. (1993). Gli effetti economici dell'immigrazione sul paese di destinazione. Economia \& Lavoro, 1, 93-105.

72. OECD. 2005: The economic impact of migration. Economic Surveys 7.

73. Blumer, H. (1958). Race Prejudice as a Sense of Group Position. Pacific Sociological Review, 1, 3-7.

74. Bersani, E.B. (2012). An Examination of First and Second Generation Immigrant Offending Trajectories. Justice Quarterly, 31(2), 315-343. doi: 10.1080/07418825.2012.659200.

75. Bersani, E.B., Loughran, A.T., \& Piquero, R.A. (2014). Comparing Patterns and Predictors of Immigrant Offending Among a Sample of Adjudicated Youth. Journal of Youth and Adolescence, 43(11), 1914-1933. doi: 10.1007/s10964-013-0045-z.

76. Lee, T.M., Martinez Jr., R., \& Rosenfeld, R. (2001). Does Immigration Increase Homicide Rates? Negative Evidence 
From Three Border Cities. The Sociological Quarterly, 42, 559-580. doi: 10.1111/j.1533-8525.2001.tb01780.x.

77. Sampson, J.R., Morenoff, D.J., \& Raudenbush, S. (2005). Social Anatomy of Racial and Ethnic Disparities in Violence. American Journal of Public Health, 95(2), 224-232. doi: 10.2105/AJPH.2004.037705.

78. Stowell, I.J., \& Martinez Jr., R. (2007). Displaced, dispossessed, or lawless? Examining the link between ethnicity, immigration, and violence. Aggression and Violent Behavior, 12(5), 564-581. doi: 10.1016/j.avb.2007.02.011.

79. Martinez, R., \& Stowell I.J. (2012). Extending Immigration and Crime Studies: National Implications and Local Settings. The Annals of the American Academy of Political and Social Science, 641(1), 174-192. doi: 10.1177/0002716212437363.

80. Coen-Pirani, D. (2011). Immigration and Spending on Public Education: California, 1970-2000. Journal of Public Economics, 95(11-12), 1386-1396. doi: 10.1016/j.jpubeco.2011.05.006.

81. Speciale, B. (2012). Does immigration affect public education expenditures? Quasi-experimental evidence. Journal of Public Economics, 96(9-10), 773-783. doi: 10.1016/j.jpubeco.2012.04.004.

82. Tanaka, R., Farre, L., \& Ortega, F. (2014). Immigration, Naturalization, and the Future of Public Education. IZA Discussion Papers 8342.

83. RAND. (2006). The Public Spends Little to Provide Health Care for Undocumented Immigrants. Research Briefs RB9230.

84. Mohanty, A.S., Woolhandler, S., Himmelstein, U.D., Pati, S., Carrasquillo, O., \& Bor, H.D. (2005). Health Care Expenditures of Immigrants in the United Stated: A Nationally Representative Analysis. American Journal of Public Health, 95(8), 1431-1438. doi: 10.2105/AJPH.2004.044602.

85. Schweitzer, R., Perkoulidis, S., Krome, S., Ludlow, C., \& Ryan, M. (2005). Attitudes towards Refugees: The Dark Side of Prejudice in Australia. Australian Journal of Psychology, 57(3), 170-179. doi: 10.1080/00049530500125199.

86. Hainmueller, J., \& Hiscox J.M. (2007). Educated Preferences: Explaining Attitudes Toward Immigration in Europe. International Organization, 61, 399-442. doi: 10.1017/S0020818307070142.

87. Facchini, G., \& Mayda M.A. (2009). Does the welfare state affect individual attitudes toward immigrants? Review of Economics and Statistics, 91, 295-314. doi: 10.1162/rest.91.2.295.

88. Strielkowski, W., \& Sanderson, M. (2013). Structural channels for ukrainian labour migration in the Czech Republic. TRAMES: A Journal of the Humanities \& Social Sciences, 17(3), 313-323. doi: 10.3176/tr.2013.3.06.

89. Paas, T., \& Halapuu, V. (2012). Attitudes towards immigrants and the integration of ethnically diverse societies. Norface Migration Discussion Paper, 2012-23.

90. Murray, E.K., \& Marx, M.D. (2013). Attitudes Toward Unauthorized Immigrants, Authorized Immigrants, and Refugees. Cultural Diversity and Ethnic Minority Psychology, 19(3), 332-341. doi: 10.1037/a0030812.

91. Hatton, J.T. (2016). Immigration, public opinion and the recession in Europe. Economic Policy, 2016, 205-246. doi: 10.1093/epolic/eiw004.

92. Hughes, M., \& Tuch, A.S. (2003). Gender Differences in Whites' Racial Attitudes: Are Women's Attitudes Really More Favorable? Social Psychology Quarterly, 66(4), 384-401. doi: 10.2307/1519836.

93. Amuedo-Dorantes, C., \& Puttitanun, T. (2011). Gender Differences in Native Preferences toward Undocumented and Legal Immigration: Evidence from San Diego. Contemporary Economic Policy, 29(1), 31-45. doi: 10.1111/j.14657287.2010.00210.x. Литва);

М. Буткус, PhD, доцент кафедри інженерної економіки, Вільнюський технічний університет ім. Гедімінаса (м. Вільнюс,

А. Мацюліте-Снікієн, $\mathrm{PhD}$, лектор кафедри бізнес-технологій та підприємництва, Вільнюський технічний університет ім. Гедімінаса (м. Вільнюс, Литва);

К. Матузєвіцю, PhD, доцент кафедри інженерної економіки, Вільнюський технічний університет ім. Гедімінаса (м. Вільнюс, Литва);

В. Давидович, PhD, професор кафедри бізнес-технологій та підприємництва, Вільнюський технічний університет ім. Гедімінаса (м. Вільнюс, Литва)

Дослідження ставлення суспільства до наслідків імміграції на прикладі країн ЄС

Однією з найбільш нагальних проблем, які на сьогодні привертають увагу громадян ЄС, є інтеграція іммігрантів. За останній період імміграційні потоки в ЄС значно зросли - на 57,5\% за 2000-2015 рр. Одним з факторів, що ведуть до успішної інтеграції іммігрантів, є ставлення суспільства до їх впливу на соціально-економічну, культурну або іншу трансформацію країн. Важливим є дослідження не лише наслідків імміграції, а й ставлення суспільства до вигод $і$ втрат від імміграції. Результати дослідження показують, що ставлення суспільства до наслідків імміграції $\epsilon$ негативним, особливо щодо впливу на криміногенну ситуацію, і це не відповідає реальному впливу, емпірично дослідженому іншими авторами і представленому в огляді літератури.

Ключові слова: ставлення до іммігрантів, наслідки імміграції, модель вигод і загроз, вигоди від імміграції, витрати від імміграції. 
М. Буткус, А. Мацюліте-Снікієн, К. Матузєвіцю, В. Давидович. Дослідження ставлення суспільства до наслідків імміграції на прикладі країн ЄС

M. Буткус, PhD, доцент кафедры инженерной экономики, Вильнюсский технический университет им. Гедиминаса (г. Вильнюс, Литва);

А. Мацюлите-Сникиен, $\mathrm{PhD}$, лектор кафедры бизнес-технологий и предпринимательства, Вильнюсский технический университет им. Гедиминаса (г. Вильнюс, Литва);

K. Матюзевицю, PhD, доцент кафедры инженерной экономика, Вильнюсский технический университет им. Гедиминаса (г. Вильнюс, Литва);

B. Давидович, $\mathrm{PhD}$, профессор кафедры бизнес-технологий и предпринимательства, Вильнюсский технический университет им. Гедиминаса (г. Вильнюс, Литва)

Исследование отношения общества к последствиям иммиграции на примере стран ЕС

Одной из наиболее насущных проблем, которая сегодня привлекает внимание граждан $E C$, является интеграция иммигрантов. За последний период иммиграционные потоки в ЕС значительно выросли - на 57,5\% за 2000-2015 г2. Одним из факторов, ведущих к успешной интеграции иммигрантов, является общественное отношение к их влиянию на социально-экономическую, культурную или другую транссформацию стран. Важным является исследование не только последствий иммиграции, но и отношения общества к выгодам и потерям от нее. Результаты исследования показывают, что отношение общества к последствиям иммиграции отрицательные, особенно в отношении воздействия на криминогенную ситуацию, и это не соответствует реальному воздействию, эмпирически исследованному другими авторами и представленному в обзоре литературы.

Ключевые слова: отношение к иммигрантам, последствия иммиграции, модель выгод и угроз, выгоды от иммиграции, потери от иммиграции.

Отримано 18.06.2017 p. 